$20 \begin{aligned} & \text { Pesquisa Florestal Brasileira } \\ & \text { Brazilian Journal of Forestry Research } \\ & \text { http://pfb.cnpf.embrapa.br/pfb/ }\end{aligned}$

\title{
Nursery and field serial grafting of Ilex paraguariensis
}

\author{
Delmar Santin ${ }^{1}$, Ivar Wendling ${ }^{2}$, Eliziane Luiza Benedetti ${ }^{3}$, Divercindo Morandi ${ }^{4}$ \\ ${ }^{1}$ Autônomo, Rua João Allage, 722, CEP 89460-000, Canoinhas, SC, Brasil \\ ${ }^{2}$ Embrapa Florestas, Estrada da Ribeira Km 111, CP 319, CEP 83411-000, Colombo, PR, Brasil \\ ${ }^{3}$ Instituto Federal de Santa Catarina, Av. Expedicionários, 2150, CEP 89460-000, Canoinhas, SC, Brasil \\ ${ }^{4}$ Autônomo, Rua Ivan Ulbrich, 935, CEP 83900-000, São Mateus do Sul, PR, Brasil
}

\section{"Autor correspondente: \\ desantinflorestal@yahoo.com.br}

Termos para indexação:

Ilex paraguariensis

Propagação vegetativa

Seleção de matrizes

Melhoramento genético

Index terms:

Ilex paraguariensis

Vegetative propagation

Selection of parent trees

Histórico do artigo:

Recebido em 28/04/2015

Aprovado em 26/11/2015

Publicado em 31/12/2015

doi: $10.4336 / 2015 . p f b .35 .84 .903$

\begin{abstract}
The long time required to produce seedlings and the formation of plantations with low-quality genetic material are problems that need to be solved in the culture of yerba mate. Grafting for new plants production or for replacement of mate plants canopy may overcome those restrictions. However, that technique still lacks better investigation, especially regarding adult genetic material. Thus, we aimed to evaluate the effect of serial grafting (subcultures), clones, grafting environments and gender of parent plants in the survival and vitality of yerba mate grafts. An experiment with seedlings in a nursery was conducted in order to evaluate 3 subcultures and 2 clones. In another experiment, field and nursery environments were compared for six clones (three male and three female). The survival and vitality of grafts were evaluated for both experiments every 35 days and at the $105^{\text {th }}$ day. The survival and vigor of grafts were affected by the clones and subcultures, there was a trend for the field ones to be superior to the nursery ones. Two subcultures were concluded to result in higher survival and vigor of yerba mate grafts, and those characteristics were concluded to be favored when grafting was directly conducted in the field and, especially, when the propagules came from female parent trees.
\end{abstract}

\section{Enxertia seriada de erva-mate em viveiro e campo}

Resumo - O longo tempo necessário para produção de mudas por semente e a formação de ervais com material genético de baixa qualidade são problemas que necessitam ser superados na cultura da erva-mate. A enxertia na produção de mudas ou na substituição da copa de ervais poderá suplantar estas restrições. No entanto, a técnica ainda carece de maiores estudos, principalmente para materiais genéticos adultos. Assim, objetivou-se avaliar o efeito da enxertia seriada (subcultivos), clones, ambientes de enxertia e sexo das plantas matrizes na sobrevivência e vigor de enxertos de erva-mate. Para avaliar 3 subcultivos e 2 clones, instalou-se um experimento com mudas em viveiro. Em outro experimento compararam-se os ambientes campo e viveiro e seis clones (três masculinos e três femininos). Para ambos os experimentos avaliaram-se a sobrevivência e o vigor dos enxertos a cada 35 dias e aos 105 dias. A sobrevivência e o vigor dos enxertos foram afetados pelos clones e subcultivos, sendo aqueles de campo com tendência de superioridade aos de viveiro para essas variáveis. Concluiu-se que dois subcultivos resultam em maior sobrevivência e vigor de enxertos de erva-mate e que aquelas características são favorecidas quando a enxertia é realizada diretamente em campo e, principalmente, quando os propágulos são oriundos de matrizes femininas. 


\section{Introduction}

Yerba mate (Ilex paraguariensis) is a perennial and long-living tree species occuring naturally in South America's subtropical regions. In Brazil, it predominates in South region (Carvalho, 2003). Yerba mate is mainly grown in small and medium-sized farms, where it is responsible for the income of thousands of workers. Research has demonstrated that yerba mate can be classified as a healthy food, and it plays functional roles in the human body, mainly due to the antioxidant substances that can be found in its leaves (Gugliucci, 1996; Mejía et al., 2010; Berté et al., 2011), and that fact may drive consumption from new products.

A great deal of yerba mate fields in Brazil was established through seedlings from parent trees that had not been selected through adequate criteria (Sturion \& Resende, 2010). That has favored the formation of lowyielding mate fields with poor-quality leaves, and that results in negative aspects of the final product (Wendling $\&$ Brondani, 2015). That may jeopardize the whole production system.

Grafting has been the most used method in the production of clonal orchards for producing improved seeds, in order to broaden the genetic base after selected parent trees are recombined, to multiply superior genotypes, and to create clonal banks (Xavier et al., 2013). By using propagules from the adult part of a parent tree, plants obtained through grafting reach their flowering stage quicker and canopies grow to lower heights, which makes seeds harvesting easier (Hartmann et al., 2011). However, if the goal is to multiply superior parent trees for increasing productivity and growing clonal fields, juvenile propagules must be used (Wendling et al., 2014a).

In that sense, the grafting technique in forest species has become an efficient method for rejuvenation/ reinvigoration, in which mature propagules are grafted on the juvenile parts of a rootstock, which enables the cuttings from those sprouts to be more able to root (Wendling et al., 2014b). For Huang et al. (1990), serial grafting is the most consistent method and the most used one for rejuvenation of plants or their mature parts. In yerba mate, besides grafting being used as a method to multiply clones (Wendling et al., 2009), what is intended with the technique is to induce rejuvenation through successive grafting, in order to obtain a higher percentage of rooted cuttings (Niklas, 1990) and the replacement of canopies (Wendling et al., 2009; Wendling \& Brondani, 2015 ) in adult fields with low-quality plants.

Vegetative propagation is influenced by several factors, among which species, climate, and physiological conditions of parent trees (Eldridge et al., 1994; Xavier et al., 2013). For yerba mate, especially, variation of vegetative propagation ability among different individuals is high (Prat Kricun et al., 1986; Tavares et al., 1992; Domingos \& Wendling, 2006). This makes the execution of studies important, to investigate factors related to parent trees, rejuvenation, and grafting environment for this species. Thus, we evaluated the effect of serial grafting (subcultures), clones, grafting environments and gender of parent trees in the survival and vigor of yerba mate grafts.

\section{Material and methods}

The experiments started in August 2005 in São Mateus do Sul, PR state, Brazil, at company Baldo S/A (longitude $50^{\circ} 26^{\prime} 30^{\prime \prime} \mathrm{O}$ latitude $25^{\circ} 54^{\prime} 33^{\prime \prime} \mathrm{S}$ and $800 \mathrm{~m}$ above sea level). The region has a temperate climate $(\mathrm{Cfb})$, with an average annual rainfall rate between 1,600 and 1,800 mm (IAPAR, 1994). In São Mateus do Sul, during the experimental period (August, September, October, and November 2005), rainfall rates were, respectively 129, 288, 321, and $83 \mathrm{~mm}$ (Alturas..., 2015).

Two experiments were developed, the first of which having a factorial design $(2 \times 3 \times 3)$, by comparing two clones (clone 1 and clone 2), three subcultures (subculture I, II, and III), and three evaluation periods $\left(35^{\text {th }}, 70^{\text {th }}\right.$, and the $105^{\text {th }}$ day). The second in a factorial design ( $6 \times 2 \times 3)$, by comparing six clones, two environments (field and nursery), and three evaluation periods $\left(35^{\text {th }}, 70^{\text {th }}\right.$, and the $105^{\text {th }}$ day). Clone gender factor was evaluated at the end of the second experiment $\left(105^{\text {th }}\right.$ day). Thus, for the variables that were only evaluated at the end of the experiment, a factorial design of $6 \times 2 \times$ 2 was created, with six clones, two environments, and two genders. A randomized block design was used for both experiments. It included five repetitions, and the experimental unit comprised five grafted yerba mate plants or seedlings.

Top cleft grafting was the used method for both experiments (Figure 1). Shoots from the rootstock were cut, with no lateral branches being left (Figure 1A); that was followed by a $5 \mathrm{~cm}$ vertical incision through the 
piths, where grafts with two or three buds and wedgeshaped ends were inserted (Figure 1B). Both rootstocks and scions were fastened together with a plastic ribbon. Afterwards, the grafted region was wrapped with a plastic bag and then a parchment paper bag (Figure 1C), respectively in order to keep the humidity in the location and to protect grafts from sunrays (Wendling et al., 2004; Domingos \& Wendling, 2006). Around 25 days after that, little holes were punched in the paper and plastic bags for acclimatization purposes - bags were taken off after 35 days after grafting, when rootstocks and scions had already inosculated (Figure 1D). The grafts were submitted to a $60 \%$ shade level (as gauged by a lux meter), and that was provided by the shade in the understory of local native trees. Shade was provided by a shade screen in the nursery.
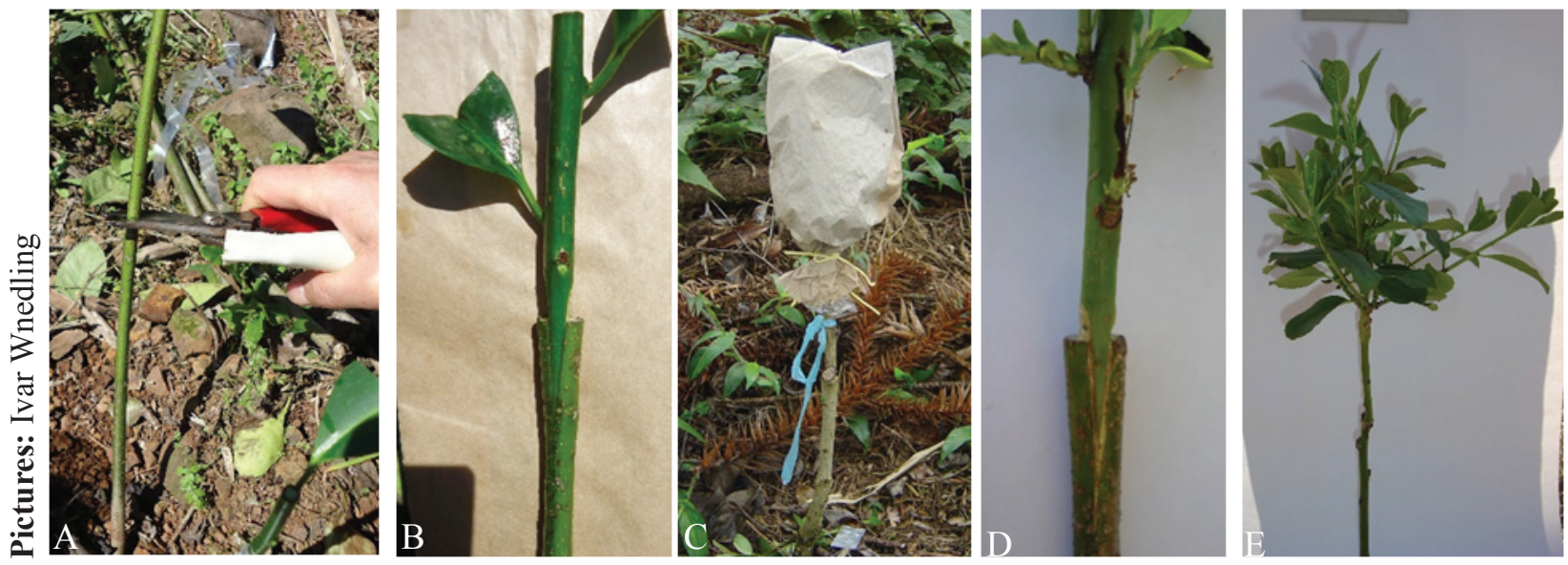

Figure 1. Top cleft grafting. Shoot removal from rootstock (A), inserting wedge-ended scion in a rootstock (B), covering the graft with a plastic and a paper bag (C), inosculation of a scion and a rootstock after ribbon removal (D); and budding scion at the $105^{\text {th }}$ day after the grafting of yerba mate $(\mathrm{E})$.

Experiment 1: Clones and subcultures employed in the nursery grafting

For rootstocks, 18 month-old seedlings were used; they were produced in $8 \mathrm{~cm} \times 12 \mathrm{~cm}$ plastic packages. The scions for subculture I were collected from the bottom of the canopies of a female (clone 1) and of a male parent tree (clone 2), both of which being approximately 80 years old. The second and the third subcultures consisted of the grafting of propagules that had been respectively collected from the buds from subcultures I and II. They were grafted in 2003 and 2004 (Figure 2).

On the $35^{\text {th }}, 70^{\text {th }}$, and the $105^{\text {th }}$ day after grafting, grafts were evaluated for survival percentage, number of buds taller than $1 \mathrm{~cm}$, and lack of buds. At the $105^{\text {th }}$ day, the average number of buds (ANB) and the average bud length $(\mathrm{ABL})$ were evaluated for each scion.

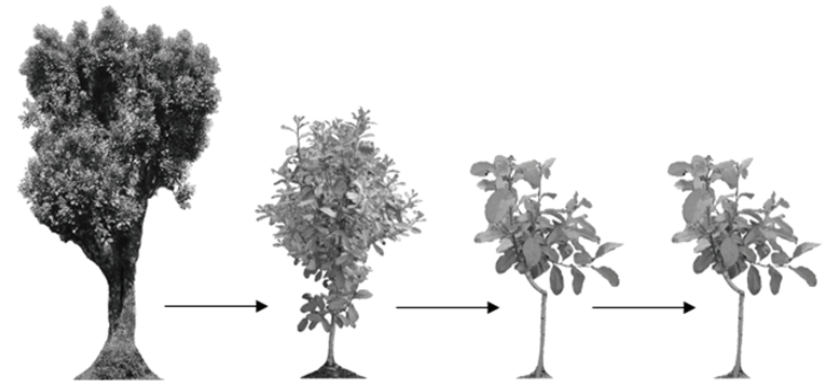

Parent tree Subculture I Subculture II Subculture III

Figure 2. Procedural sequence of yerba mate serial grafting from the adult parent tree to the third subculture (I, II, and III).

Experiment 2: Clones, environments, and gender of parent trees employed in the nursery and field grafting.

Field and nursery grafting methods were compared for six clones, three of which being female (F1, F2, and 
F3) and the other three, male (M1, M2, and M3). The propagules for grafting all clones came from subculture II, according to the details in Experiment I. For the field grafting, five-year old yerba mate scions were used. They had been cut at soil level 12 months before the grafting, in order to induce new sprouts. The forest environment was managed three years before the seedlings were planted in the field, with Ocotea porosa, Cedrela fissilis, Ilex paraguariensis, and Mimosa scabrella trees being left as the predominant ones in the area. The yerba mate seedlings were planted in the space that was cleared by the forest partial removal, which characterized a highdensity mate field (Da Croce \& Floss, 1999); that was the typical in the studied region. 18 month-old seedlings were used in the nursery environment as rootstocks; they were produced in $8 \mathrm{~cm} \times 12 \mathrm{~cm}$ plastic packages.

On the $35^{\text {th }}, 70^{\text {th }}$, and the $105^{\text {th }}$ day after grafting, grafts were evaluated for survival percentage, number of buds taller than $1 \mathrm{~cm}$, and lack of buds in the grafts. At the $105^{\text {th }}$ day, grafts were evaluated for survival (only for gender factor), ANB, and ABL. The data from both experiments were submitted to analysis of variance (ANOVA) and the averages of variables were analyzed through a 5\% probability Tukey test.

\section{Results and discussion}

\section{Clones and subcultures in the nursery grafting}

The interaction between clones, subcultures, and evaluation periods was significant for survival and vigor of grafts (Figures 3A, B, and $\mathrm{C}$ ). The average number of buds (ANB) and the average bud length (ABL) were evaluated on the $105^{\text {th }}$ day after grafting and observed to be affected by the interaction between clones and subcultures (Figures 3D and E). The survival was reduced as the evaluation period elapsed, with the exception of clone 2 from the first subculture (Figure $3 \mathrm{~A})$. At the $105^{\text {th }}$ day after grafting, the grafts from clone $1(60 \%)$ had a higher survival rate than the ones from clone $2(0 \%)$ in subculture I; in subculture II, clone 2 was superior to clone 1 , and in subculture III there were no differences among clones. Upon comparing the subcultures in each clone at the $105^{\text {th }}$ day, the survival of grafts from clone 1 was higher in subcultures I and II; for clone 2 , however, it was only superior in subculture
II. While conducting field grafting with propagules from yerba mate parent trees of approximately 70 years old, Domingos \& Wendling (2006) found a survival rate of over $56 \%$ (first subculture) at the $90^{\text {th }}$ day after grafting, which was similar to the result obtained in this study.

The fact that clone 2 (in subculture I at 35 days postgrafting) was only observed to have $4 \%$ of living grafts (Figure 3A) caused the bud that was taller than $1 \mathrm{~cm}$ (Figure 3B) and the lack of buds (Figure 3C) for clone 2 in subculture I to tend to zero. Regarding the percentage of grafts whose buds exceed $1 \mathrm{~cm}$, a different behavior was also observed among clones (Figure 3B).

Juvenility is considered one of the main factors for successful vegetative propagation of forest species (Huang et al., 1990; Menzies, 1992; Wendling et al., 2014a) and one of the possible ways to revert it is through serial grafting (Wendling et al., 2014b). That technique may reinvigorate/rejuvenate adult trees by reducing the distance between where buds are formed at the canopy to the plants root system, or by changing bud conditions through the physiological effects from a newly-formed root system (Franclet et al., 1987; Danthu et al., 2002; Greenwood et al., 2010). Two to six serial grafting procedures have been recommended for obtaining rejuvenation for forest species (Eldridge et al., 1994; Assis, 1996), and that fact was confirmed in this study, in which better survival rates for grafts were obtained after two subcultures, and that characteristic is related to more juvenile materials (Greenwood et al., 2010).

Regarding subcultures influence in the percentage of buds taller than $1 \mathrm{~cm}$ within each clone, clone 1 in subculture II was superior to the remaining subcultures as evaluated on the $35^{\text {th }}$ day. On the $70^{\text {th }}$ and $105^{\text {th }}$ day, clone 1 in subculture III was inferior. Clone 2 was showed superior results in subculture II when compared to subcultures I and III in all evaluated periods (Figure 3B). Regarding the evaluated period, subculture I stood out regarding buds taller than $1 \mathrm{~cm}$, with $64 \%$ and $60 \%$, respectively, at the $70^{\text {th }}$ day in subculture II and at the $105^{\text {th }}$ day in subculture I. In clone 2, also the periods of $70(76 \%)$ and 105 days (68\%), both in subculture II, stood out regarding that variable. The higher percentage of grafts with buds taller than $1 \mathrm{~cm}$, in clone 1, was observed to take place in different subcultures due to the periods. However, clone 2 performed well in all periods in subculture II. 

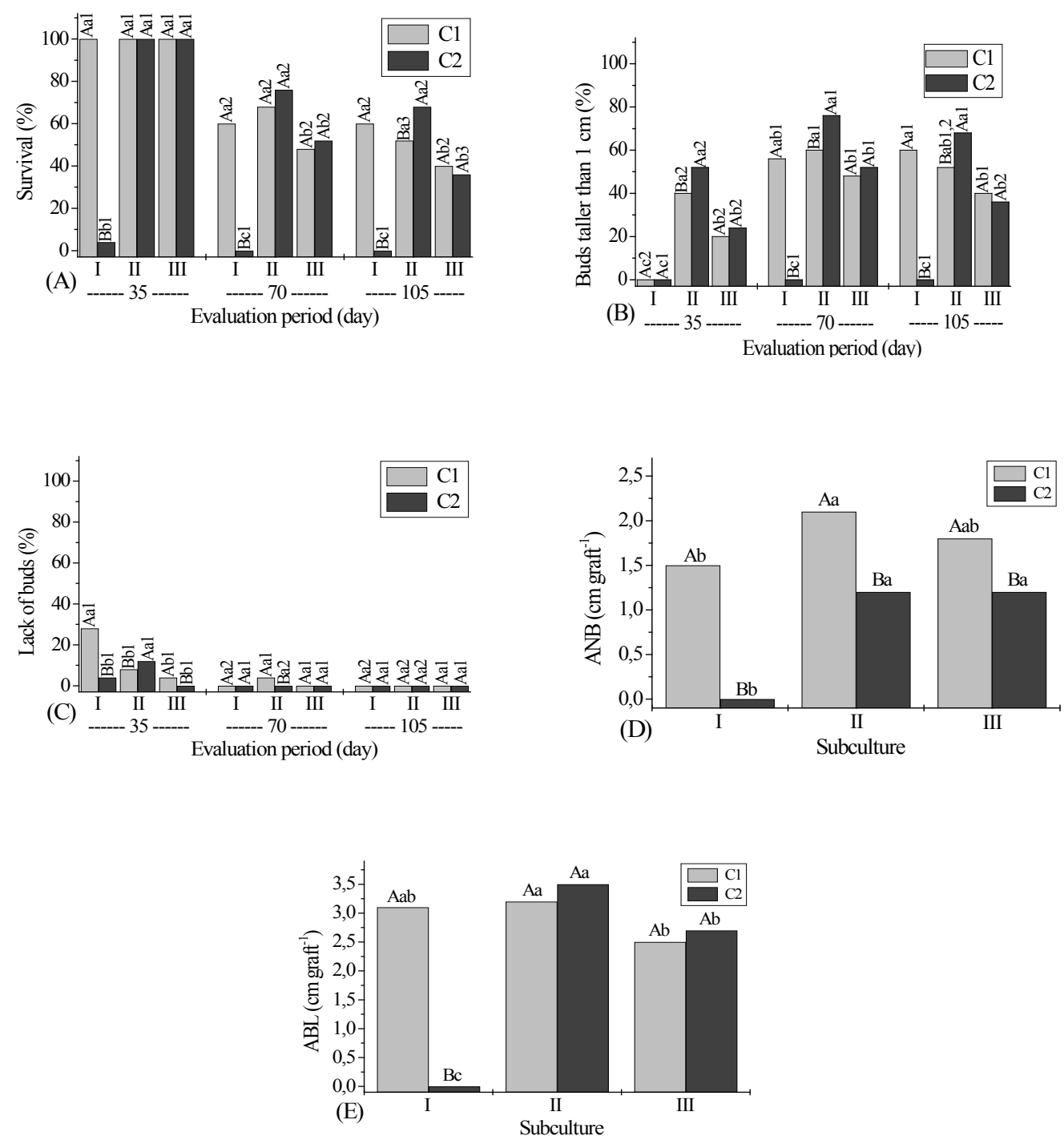

Figure 3. Survival (A), buds taller than $1 \mathrm{~cm}(B)$, lack of buds (C), which were evaluated in three evaluation periods at 35-day intervals; average number of buds (ANB) (D) and average bud length $(\mathrm{ABL})(\mathrm{E})$ of yerba mate clone grafts $(\mathrm{C} 1$ and $\mathrm{C} 2)$, which were evaluated on the $105^{\text {th }}$ day after grafting, regarding three subcultures (I, II and III). Averages followed by at least one same capital letter do not differ among clones; by the same uncapitalized letter, they do not differ among subcultures; and, by the same number, they do not differ among periods at a 5\% probability level through Tukey test.

On the $70^{\text {th }}$ day, only a small fraction (4\%) of the living grafts from clone 1 did not have buds (Figure 3C). On the $35^{\text {th }}$ day after grafting, clone 1 presented a superior result to clone 2 in subcultures I and III, whereas clone 2 was superior to clone 1 in subculture II. Regarding the average number of buds per graft (Figure 3D), which was evaluated on the $105^{\text {th }}$ day after grafting, clone 1 was superior to clone 2 in the three subcultures (Figure 3D). Upon comparing subculture effects, clone 1 was superior in subculture II (2.1 buds per graft) to subculture I (1.5 buds per graft). Regarding clone 2, subcultures I and III (with 1.2 buds per graft) were statistically superior to subculture I. Comparisons of this characteristic within each culture revealed that clone 1 outdid clone 2 regarding the average number of buds per graft by 100 , 75 , and $50 \%$, respectively, for subcultures I, II, and III (Figure 3D). 
The average bud lengths of grafts (Figure 3E) from clone 2 were only significantly inferior to clone 1 in subculture I, and that result is related to the death of all grafts from clone 2 in up to the $70^{\text {th }}$ day after grafting (Figure 3A). There were no differences among clones for the remaining subcultures regarding the average bud length. Regarding clones for the same variable, clone 1 in subculture II was superior to subculture III, without differing from subculture I, and clone 2 in subculture II was superior to the remaining subcultures (Figure 3E).

Differences were found between clones for most studied variables (Figure 3). Varying vegetative propagation abilities are often observed among yerba mate plants (Tavares et al., 1992), and there is a need for specific propagation protocols for each clone to be developed (Wendling \& Brondani, 2015). The clones are also another key factor for the successful grafting of that species, as it influences success in the technique, as also concluded by Wendling et al. (2009).

In most studies analyzing yerba mate grafting, the aim is to obtain higher percentages of living grafts, which a high number of strong and healthy buds (Niklas, 1990; Wendling et al., 2004, 2009; Domingos \& Wendling, 2006). Thus, grafts need to have a high percentage of buds taller than $1 \mathrm{~cm}$ in the shortest time following grafting. In that sense, clone 2 in subculture II on the $70^{\text {th }}$ and on the $105^{\text {th }}$ days after grafting, showed a relatively higher survival rate ( 76 and $68 \%$, respectively) (Figure 3A) and number of buds taller than $1 \mathrm{~cm}(76$ and $68 \%$, respectively) (Figure 3B). The indication of two subcultures for yerba mate grafting is reinforced by the higher percentage of grafts with average number of buds for clone 1 (Figure 3D) and average bud length, for both clones (Figure $3 \mathrm{E}$ ), on the $105^{\text {th }}$ day after grafting. These results show that, for grafting on yerba mate seedlings, two subcultures are enough to obtain higher graft survival and vigor rates.

\section{Clones, environments, and gender of parent trees in the grafting}

Characteristics survival, number of buds taller than 1 $\mathrm{cm}$, and lack of buds, which were evaluated at different times, were influenced by the interaction of clones, environments, and evaluation periods (Figure 4). At the $105^{\text {th }}$ day after grafting, survival was influenced by the clone genders (Figure 5A); and average bud length was influenced by the interactions clone $\mathrm{x}$ environment (Figure 5C) and gender $\mathrm{x}$ environment (Figure 5D).
The average number of buds was only influenced by the interaction between clone and environment (Figure 5B).

The survival of grafts reduced as the evaluation periods elapsed. At the $105^{\text {th }}$ day, only clones F1, F3, M2, and $\mathrm{M} 3$ showed survival rates that were the same as the one from the $70^{\text {th }}$ day in the field environment. For those same clones that were grafted in the nursery, as well as the remaining ones from both environments, survival on the $105^{\text {th }}$ day was inferior to the one evaluated on the $70^{\text {th }}$ day. The graft survival in the nursery was only superior to the one in the field on the $70^{\text {th }}$ day for clones F1, F2, and M2. The highest graft survival in the field was observed on the $35^{\text {th }}$ day for clone $\mathrm{F} 1$, on the $75^{\text {th }}$ day for F3, and on the $105^{\text {th }}$ day for F1, F3, M1, and M3. In a similar way to experiment 1 , varying results were found among clones, and that corroborates previous results for yerba mate (Domingos \& Wendling, 2006; Brondani et al., 2008; Wendling et al., 2009). In this study, on the $105^{\text {th }}$ day after grafting, besides clone factor having been observed to influence graft survival, a superiority trend was observed for the field environment for this variable, and that fact runs contrary to the one found by Niklas (1990), whose nursery grafts were observed to be more successful than the field ones.

For buds taller than $1 \mathrm{~cm}$, nursery grafting was superior to the field one for clones F2 and M2 on the $35^{\text {th }}$ day, and for clone M3 on the $70^{\text {th }}$ day (Figure 4B). Superiority of field grafting was observed in clone F3 on the $70^{\text {th }}$ day and in clones F3 and M1 on the $105^{\text {th }}$ day. On the $35^{\text {th }}$ day, clone F2 in the nursery and clone M1 in the nursery and field were showed the highest number of grafts with buds taller than $1 \mathrm{~cm}$. On the $70^{\text {th }}$ day, clone F3 in the nursery was inferior to the remaining ones. On the $105^{\text {th }}$ day, clones M1 and M3, respectively, in the nursery and in the field, presented the smallest rate of grafts with buds shorter than $1 \mathrm{~cm}$.

The percentage of grafts with no buds reduced as the evaluation periods elapsed for the nursery grafting of all clones. For field grafting, on the other hand, this effect was only verified for clone 2 (Figure 4C). That means that, on the $35^{\text {th }}$ day after grafting, most grafted clones in the field already had buds, whereas a great deal of the ones in the nursery had not sprouted yet. For field grafting, clone $\mathrm{M} 3$ on the $35^{\text {th }}$ and $70^{\text {th }}$ day, was most observed to have grafts with no buds. No significant differences were found for clones in both grafting environments for that variable on the $105^{\text {th }}$ day. 

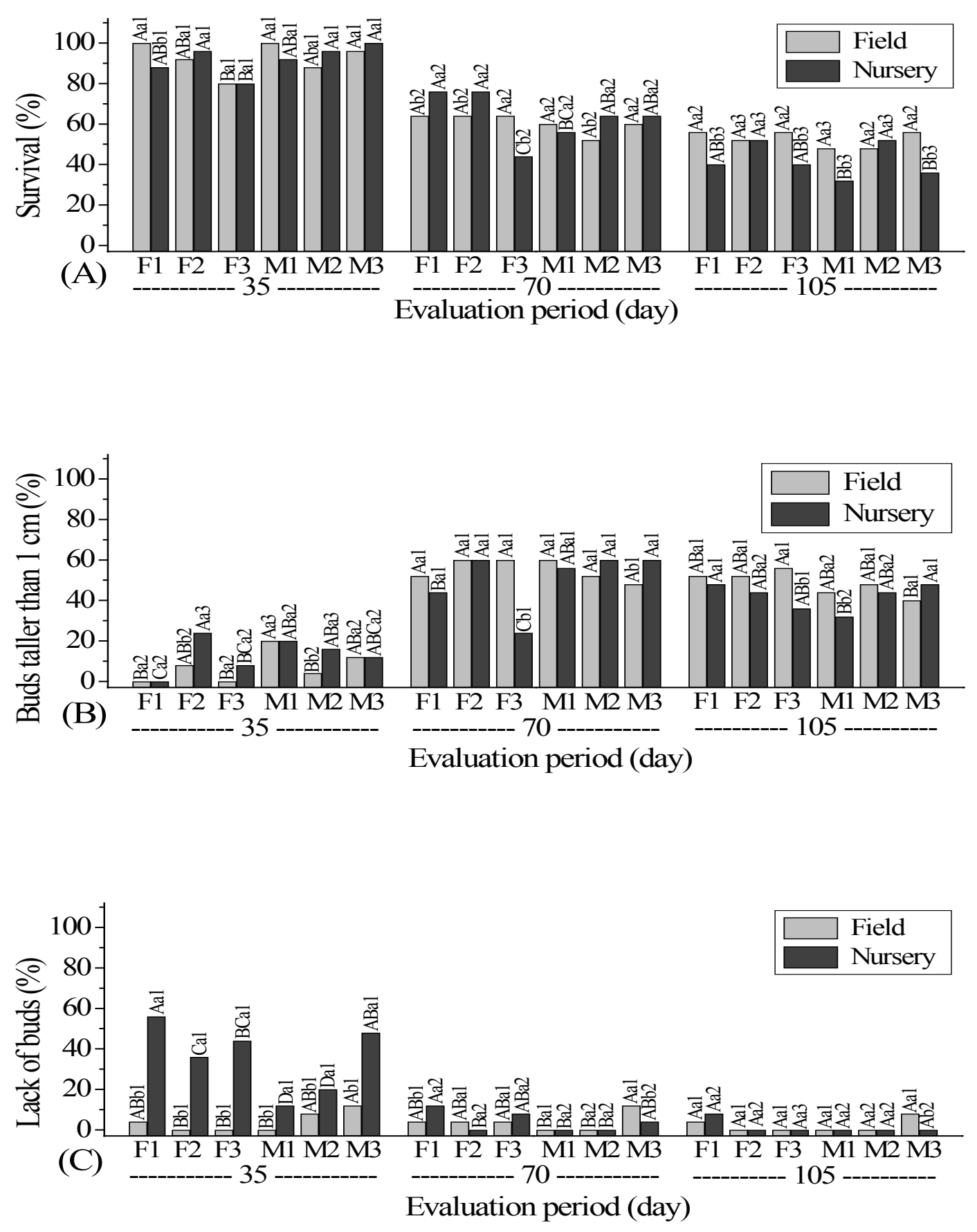

Figure 4. Survival (A), buds taller than $1 \mathrm{~cm}(B)$, lack of buds (C) from yerba mate clones that were grafted in field and nursery environments, evaluated in three periods at 35-day intervals. Averages followed by the same capital letter do not differ among clones; by the same uncapitalized letter, they do not differ among environments; and, by the same number, they do not differ among periods at a 5\% probability level through Tukey test. 
Inosculation periods vary within species. In citrus trees, complete lignification is only achieved around 40 days after grafting (Hartmann \& Kester, 1990). For Eucalyptus dunnii grafting, most grafts had already sprouted on the $30^{\text {th }}$ day (Moraes et al., 2013). Successful grafting depends on the union between rootstocks and scions (Janick, 1966). Generally, from the first moment of contact between scions and rootstocks until complete graft inosculation, parenchymal cells are produced and interwoven in the rootstock; a new cambium is produced in the callus region; and, finally, new xylem and phloem are formed from the new vascular callus that was produced in the callus region (Hartmann \& Kester, 1967), thus forming a new connection between the root system (rootstock) and the canopy (scion) (Janick, 1966). For yerba mate, there are still no studies on inosculation times in the grafting of seedlings and plants in the field. Nonetheless, the differences among clones regarding their percentages of buds taller than $1 \mathrm{~cm}$ and lack of buds (Figures $4 \mathrm{~B}$ and $\mathrm{C}$ ) are clues indicating that for this species, physiological differences can be verified both among male and female plants (Rakocevic et al., 2009) and among plants of the same gender.

Survival (Figure 5A) and bud length of grafts average (Figure 5D) were influenced by clone gender on the $105^{\text {th }}$ day. The female clones with $49 \%$ survival were superior to the male ones (45\%) (Figure 5A). Female clones were superior concerning average bud length to the male ones in field grafting, and the male ones were observed to be superior in the nursery grafting (Field grafting 5D).

The grafts in the field environment were considerably superior, both for the average number of buds (Figure 5B) and for the average bud length (Figures 5C and D). Management interventions in the aerial part of plants normally affect their root activities (Lehmann, 2003) and, most times, pruning causes the balance between the assimilation surface (leaves) and the water and nutrient absorption surface (thin roots) to be tipped (Ehsen, 1987), which causes the death of a large number of roots (Thomaziello \& Pereira, 2008). The continuous replacement of fine roots allows plants to explore a higher soil volume (Freitas et al., 2008), which is important to replace and increase biomass (McClaugherty et al., 1985; Vogt et al., 1986). In this sense, the rootstock that is already established in the field probably has more developed root system with a large soil area to explore. These aspects provide better conditions for vegetative growth of scions as compared to the rootstocks that grow inside plastic bags, with root expansion limitations, a factor which might also have contributed to the higher percentage survival of grafts, average number of buds, and average bud length in the field. The predominance of increased survival (Figure 4A) and increased vigor (Figures 5B, C, and D) of grafts in field environment, at the end of the experiment $\left(105^{\text {th }}\right.$ day), indicates field grafting is more promising for yerba mate than the nursery one.

Regarding the average bud length, while comparing the clones within each environment, clone F1 was superior to the remaining ones under field conditions (Figure 5C). Also considering that characteristic according to the clone genders (Figure 5D), field grafting was observed to be superior to the nursery one. However, the female clones were observed to have smaller average bud length in the nursery, as compared to the male ones (Figure 5E). The morphophysiologies of different genders individuals may significantly impact the production of raw materials (Ho, 1988). In yerba mate plants, sexual dimorphism influences physiology, in that there is increased photosynthesis in female plants as compared to male ones, especially in the vegetative stages that precede flowering and fruit maturation (Rakocevic et al., 2009). Besides that, male plants are more sensitive to environmental changes than female ones (Rakocevic \& Martim, 2011). These physiological differences may have favored the increased vigor of female clones in the field. 

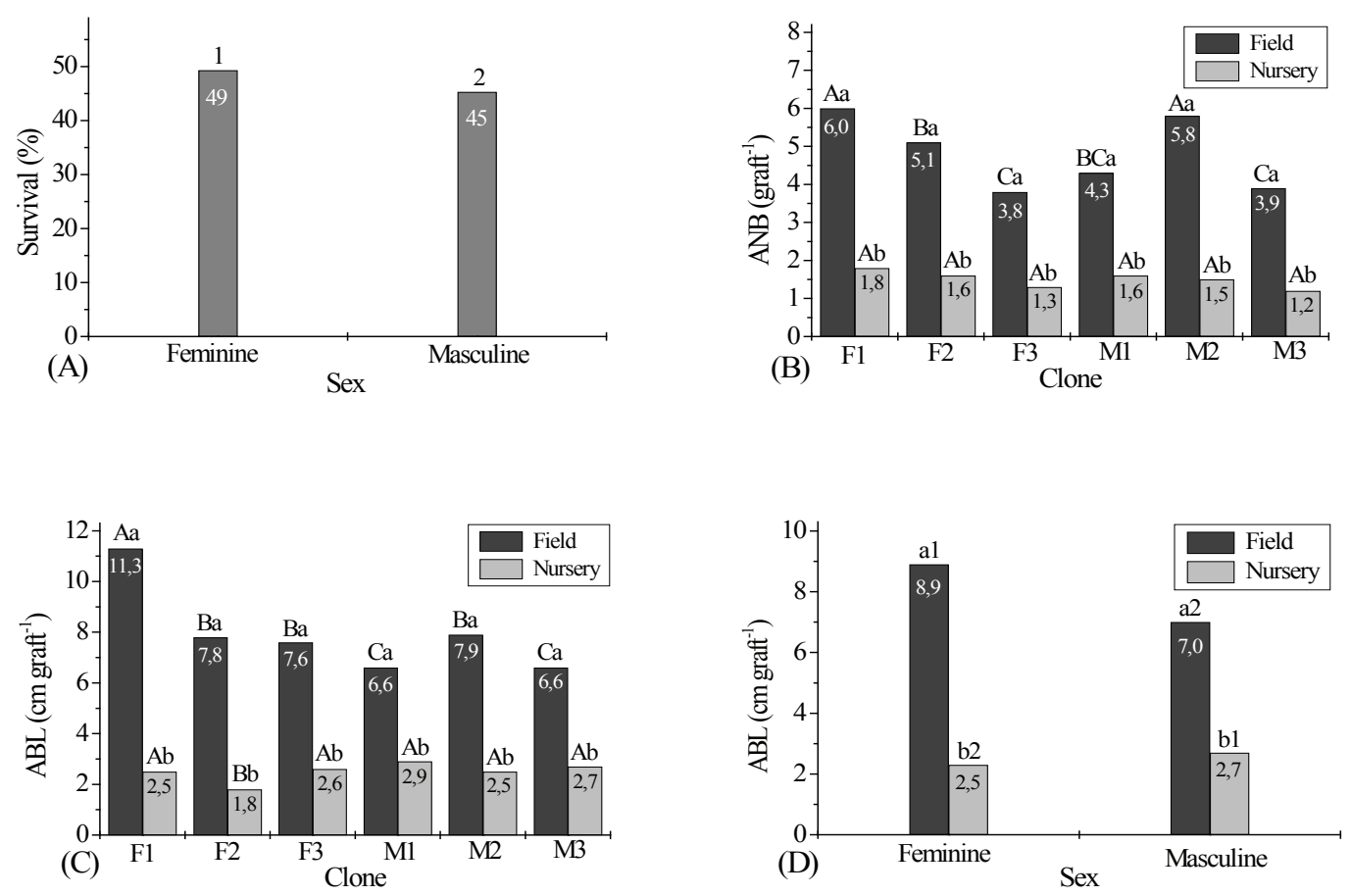

Figure 5. Survival (A), average number of buds (ANB) (B), average bud length (ABL) (C and D) of grafts from female (F) and male (M) yerba mate clones, 105 days after grafting conducted in field and nursery environments. Averages followed by the same capital letter do not differ among clones; by the same uncapitalized letter, they do not differ among environments; and, by the same number, they do not differ among genders at a 5\% probability level through Tukey test.

\section{Conclusions}

Two re-grafting procedures already result in significant improvement of survival and vigor rates for yerba mate grafts in nursery environments.

The grafting of yerba mate plants in alreadyestablished field rootstocks results in increased survival and vigor of scions. Scions from propagules of female parent trees are more vigorous than the ones from male plants.

\section{References}

ALTURAS diárias de precipitação 2005: Estação Meteorológica São Mateus do Sul. Curitiba: Secretaria do Meio Ambiente e Recursos Hídricos; Instituto das Águas do Paraná, 2015. 4 p.

ASSIS, T. F. Melhoramento genético do eucalipto. Informe Agropecuário, Belo Horizonte, v. 18, n. 185, p. 32-51, 1996.

BERTÉ, K.; RUCKER, N.; RIBANI, R. H. Yerba mate Ilex paraguariensis A. St.-Hil. Phytothérapie, v. 9, p. 180-184. 2011. DOI: $10.1007 / \mathrm{s} 10298-011-0629-2$.

BRONDANI, G. E.; ARAUJO, M. A.; WENDLING, I.; KRATZ, D. Enraizamento de miniestacas de erva-mate sob diferentes ambientes. Pesquisa Florestal Brasileira, Colombo, n. 57, p. 29-38, 2008.
CARVALHO, P. H. R. Espécies arbóreas brasileiras. Brasília, DF: Embrapa Informação Tecnológica; Colombo: Embrapa Florestas, 2003. 1039 p.

DA CROCE, D. M.; FLOSS, P. A. Cultura da erva-mate no Estado de Santa Catarina. Florianópolis: Epagri, 1999. 81 p. (Epagri. Boletim técnico, 100).

DANTHU, P.; HANE, B.; SAGNA, P.; GASSAMA, Y. K. Restoration of rooting competence in mature Faidherbia albida, a Sahelian leguminous tree, through serial root sucker micrografting. New Forests, Dordrecht, n. 24, p. 239-244, 2002.

DOMINGOS, D. M.; WENDLING, I. Sobrevivência e vigor vegetativo de plantas de erva-mate (Ilex paraguariensis a. St.- Hil.) enxertadas diretamente a campo. Ciência Florestal, Santa Maria, RS, v. 16, n. 1, p. 107-112, 2006.

EHSEN, H. Pruning of street trees: cause, objective and execution. Arboricultural Journal, Dorchester on Thames, v. 11, p. 245-263, 1987.

ELDRIDGE, K.; DAVIDSON, J.; HARDWIID, C.; Van WYK, G. Eucalypt domestication and breeding. Oxford: Clarendon Press, 1994. p. $228-246$.

FRANCLET, A.; BOULAY, M.; BEKKAOUI, F.; FOURET, Y.; VERSCHOORE-MARTOUZET, B.; WALKER, N. Rejuvenation. In: BONGA, J. M.; DURZAN, D. J. (Ed.). Cell and tissue culture in forestry. Dordrecht: Martinus Nijhoff, 1987. p. 232-248. 
FreitAS, T. A. S.; BARROSO, D. G.; CARNEIRO, J. G. A. Dinâmica de raízes de espécies arbóreas: visão da literatura. Ciência Florestal, Santa Maria, RS, v. 18, n. 1, p. 133-142, 2008.

GREENWOOD M. S.; DAY, M. E.; SCHATZ, J. Separating the effects of tree size and meristem maturation on shoot development of grafted scions of red spruce (Picea rubens Sarg.). Tree Physiology, Oxford, v. 30, n. 4, p. 459-468, 2010. DOI: 10.1093/treephys/tpq004.

GUGLIUCCI, A. Antioxidant effects of Ilex paraguariensis: induction of decreased oxidability of human LDL in vivo. Biochemical and Biophysical Research Communications, Quebec, v. 224, n. 2, p. 338-344, 1996.

HARTMANN, H. T.; KESTER, D. E.; DAVIES JUNIOR, F. T.; GENEVE, R. L. Plant propagation: principles and practices. 8th ed. São Paulo: Prentice-Hall, 2011. 915 p.

HARTMANN, H. T.; KESTER, D. E. Propagación de plantas. Ciudad de Méjico: Continental, 1967. 112 p.

HARTMANN, H. T.; KESTER, D. E. Propagation de plantas, principios y practicas. Ciudad de Méjico: Continental, 1990. 760 p.

HO, L. C. Metabolism and compartmentation of imported sugars in sink organs in relation to sink strength. Annual Review of Plant Physiology and Plant Molecular Biology, Los Angeles, n. 39, p. 355-378, 1988. DOI: 10.1146/annurev.pp.39.060188.002035.

HUANG, L. C.; CHIU, D. S.; MURASHIGE, T.; GUNDY, M, E. F. M.; NAGAI, K.; ALFARRO, F. P. Rejuvenation of trees and others perennials for restoration of plant regeneration competence. In: TORRES, A. C.; CALDAS, L. S. (Ed.). Técnicas e aplicações da cultura de tecidos em plantas. Brasília, DF: ABCTP/EMBRAPACNPH, 1990. p. 252-264.

IAPAR. Cartas climáticas básicas do Estado do Paraná. Londrina, 1994. $49 \mathrm{p}$.

JANICK, J. A ciência da horticultura. Rio de Janeiro: Freitas Bastos, 1966. 485 p.

LEHMANN, J. Subsoil root activity in tree-based cropping systems. Plant and Soil, Netherland, v. 255, n. 1, p. 319 -331, 2003. DOI: 10.1023/A:1026195527076.

McClaugherty, C. A.; ABER, J. D.; Melillo, J. M. Decomposition dynamics of fine roots in forested ecosystems. Oikos, Copenhagen, v. 42, n. 3, p. 378-386, 1985. DOI: 10.2307/3544408.

MEJÍA, E. G.; SONG, Y. S.; HECK, C. I.; RAMÍREZ-MARES, M. V. Yerba mate tea (Ilex paraguariensis): Phenolics, antioxidant capacity and in vitro inhibition of colon cancer cell proliferation. Journal of Functional Foods, v. 2, n. 1, p. 23-34, 2010. DOI:10.1016/j. jff.2009.12.003.

MENZIES, M. I. Management of stock plants for the production of cutting material. In: SYMPOSIUM MASS PRODUTION TECHNOLOGY FOR GENETICALLY IMPROVED FAST GROWING FOREST TREE SPECIES, Bordeaux. Syntheses... Bordeaux: AFOCEL: IUFRO, 1992. p. 145-158.

MORAES, C. B.; SILVA, P. H. M.; ABÍLIO, F. M.; PIERONI, G. B.; GONÇALVES, A. N.; MORI, E. S. Sobrevivência de enxertos de Eucalyptus com metodologia adaptada Piracicaba: IPEF, 2013. (IPEF. Circular técnica, 206).
NIKLAS, O. C. Injertacion de yerba mate. Citrus Misiones, Misiones, v. 20, p. 7-9, 1990.

PRAT KRICUN, S. D.; BELINGHERI, L. D.; PICCOLO, G. A.; FLORES, S. E. R. E FONTANA, H. P. Yerba mate: informe sobre investigaciones realizadas, período 1984-85. Cerro Azul: INTA, Estación Experimental Agropecuaria Cerro Azul, 1986. 32 p. (Miscelánea, 15).

RAKOCEVIC, M.; MARTIN, S. F. Time series in analysis of yerbamate biennial growth modified by environment. International Journal Biometeorology, v. 55, n. 2, p. 161-171, 2011. DOI: 10.1007/s00484-010-0322-4.

RAKOCEVIC, M.; MEDRADO, M. J. S.; MARTIM, S. F.; ASSAD, E. D. Sexual dimorphism and seasonal changes of leaf gas exchange in the dioecious tree Ilex paraguariensis grown in two contrasted cultivation types. Annals Applied Biology, v. 154, n. 2, p. 291-301, 2009. DOI: $10.1111 /$ j.1744-7348.2008.00298.x.

STURION, J. A.; RESENDE, M. D. V. Melhoramento genético da erva-mate. Colombo: Embrapa Florestas, 2010. 274 p.

TAVARES, F. R.; PICHET, J. A.; MASCHIO, L. M. A. Alguns fatores relacionados com a estaquia da erva-mate (Ilex paraguariensis $\mathrm{St}$. Hil.). In: CONGRESSO FLORESTAL ESTADUAL, 7., 1992, Nova Prata. Anais... Santa Maria, RS: UFSM, 1992. v. 2. p. 626-640.

THOMAZIELlO, R. A.; PEREIRA, S. P. Poda e condução do cafeeiro arábica. Campinas: Instituto Agronômico, 2008. 39 p. (Boletim técnico IAC, 203)

VOGT, K. A.; GRIER, C. C.; VOGT, D. J. Production, turnover, and nutrient dynamics of above and belowground detritus of world forests. Advances in Ecological Research, London, v. 15, p. 303377, 1986. DOI: 10.1016/S0065-2504(08)60122-1.

WENDLING, I.; LAVORANTI, O. J.; RESENDE, M. D. V; HOFFMAN, H. A. Seleção de matrizes e tipo de propágulo na enxertia de substituição de copa em Ilex paraguariensis. Revista Árvore, Viçosa, MG, v. 33, n. 5, p. 811-819, 2009. DOI: 10.1590/ S0100-67622009000500004.

WENDLING, I.; BRONDANI, G. E. Produção de mudas de ervamate. In: WENDLING, I.; SANTIN, D. Propagação e nutrição de erva-mate. Brasília, DF: Embrapa, 2015. p. 11-98.

WENDLING, I.; HOFFMAN, H.; LIRA, A. Influência da técnica e da origem do propágulo na enxertia de campo em erva-mate (Ilex paraguariensis Saint Hilarie). Boletim de Pesquisa Florestal, Colombo, n. 49, 47-60, 2004.

WENDLING, I.; TRUEMAN, S. J.; XAVIER, A. Maturation and related aspects in clonal forestry - Part I: concepts, regulation and consequences of phase change. New Forests, Dordrecht, v. 45, n. 4, p. 449-471, 2014a. DOI: 10.1007/s11056-014-9421-0.

WENDLING, I.; TRUEMAN, S. J.; XAVIER, A. Maturation and related aspects in clonal forestry - part II: reinvigoration, rejuvenation and juvenility maintenance. New Forests, Dordrecht, v. 45, n. 4, p. 473-486, 2014b. DOI: 10.1007/s11056-014-9415-y.

XAVIER, A.; WENDLING I.; SILVA, R. L. Silvicultura clonal: princípios e técnicas. 2. ed. Viçosa, MG: Ed da UFV, 2013. v. 1. $279 \mathrm{p}$. 